\section{Does nitric oxide protect Eucalyptus urophylla seeds under salt stress conditions?}

\author{
Thalita Maciel Pereira ${ }^{1}$ iD ; Heloisa Oliveira dos Santos ${ }^{2 *}$ iD ; Antonio Rodrigues \\ da Cunha Neto ${ }^{1}$ iD ; Fabieli Pelissari ${ }^{3}$ iD; Wilson Vicente Pereira ${ }^{4}$; Lucas \\ Amaral de Melo ${ }^{2}$
}

\begin{abstract}
The germination response of seeds under artificial stress conditions is a tool for better understanding of the survival and adaptation ability of species under natural stress conditions. The aims of this study were to evaluate the protective effect of nitric oxide during germination as well as seed vigor and seedling development of Eucalyptus urophylla under salt stress conditions. The experimental design was completely randomized, with five replications, in a $3 \times 3+1$ factorial arrangement, with three priming factors [water, sodium nitroprusside (SNP), and potassium nitrate $\left(\mathrm{KNO}_{3}\right)$ ], three germination conditions (distilled water, and the water potentials of -0.6 and $-1.2 \mathrm{MPa}$ ), and an additional control treatment (unprimed seeds). The following determinations were made: germination count at seven and fourteen days, germination speed index, primary root length, shoot length, and total length. SNP protects seeds, leading to a higher percentage of germination, as well as greater root growth and total seedling size, whereas $\mathrm{KNO}_{3}$ is not effective in protecting seeds that suffer from salt stress, which affects their physiological and morphological characteristics. E. urophylla seeds are sensitive to salt stress, and physiological priming with SNP leads to an increase in the percentage of germination, vigor, and seedling development under salinity conditions.
\end{abstract}

Index terms: physiological conditioning, sodium nitroprusside, potassium nitrate, sodium chloride, hydropriming.

\section{Óxido nítrico protege as sementes de Eucalyptus urophylla sob condições de estresse salino?}

RESUMO: A resposta germinativa de sementes submetidas à condição de estresses artificiais é uma ferramenta para melhor entendimento da capacidade de sobrevivência e adaptação das espécies em condições de estresses naturais. Objetivou-se avaliar o efeito protetor do óxido nítrico durante a germinação e vigor de sementes e desenvolvimento de plântulas de Eucalyptus urophylla sob condições de estresse salino. $O$ delineamento foi inteiramente casualizado, com cinco repetições, em esquema fatorial $3 \times 3+1$, sendo três condicionantes (água, nitroprussiato de sódio - SNP e nitrato de potássio), três condições de germinação (água destilada, e os potenciais de -0,6 e $-1,2 \mathrm{MPa}$ ), tendo como tratamento adicional, o controle (semente não condicionada). Determinouse: contagem da germinação aos sete e quatorze dias, índice de velocidade de germinação, comprimento da raiz primária, de parte aérea e total. O SNP protege as sementes possibilitando maior porcentagem de germinação, assim como promove maior crescimento de raiz e tamanho total de plântula, já o $\mathrm{KNO}_{3}$ não é eficaz protegendo as sementes, as quais sofrem com estresse salino, o que afeta suas características fisiológicas e morfológicas. Sementes de $E$. urophylla são sensíveis ao estresse salino e o condicionamento fisiológico com SNP promove o aumento da porcentagem de germinação, vigor e desenvolvimento de plântulas sob condições de salinidade.

Termos para indexação: condicionamento fisiológico, nitroprussiato de sódio, nitrato de potássio, cloreto de sódio, hidrocondicionamento.
Journal of Seed Science, v.42, e202042041, 2020

http://dx.doi.org/10.1590/ 2317-1545v42236272

\author{
*Corresponding author \\ E-mail: heloisa.osantos@ufla.br
}

Received: 7 Apr 2020. Accepted: 4 Nov 2020.

\footnotetext{
${ }^{1}$ Programa de Pós-Graduação em Agronomia/Fitotecnia, Universidade Federal de Lavras - Lavras, MG, Brasil.

${ }^{2}$ Universidade Federal de Lavras Lavras, MG, Brasil.
}

${ }^{3}$ Universidade Federal do Mato Grosso.

${ }^{4}$ Programa de Pós-Graduação em Engenharia Florestal, Universidade Federal de Lavras - Lavras, MG, Brasil. 


\section{INTRODUCTION}

Factors that affect germination of seeds of tree species can be controlled genetically and by the environment. Environmental factors may include the absence of optimal conditions for germination and seedling establishment, such as lack of water for irrigation or of groundwater and soils with high soluble salt content (Figueiredo et al., 2019).

Salt stress and water deficit are considered the abiotic stresses that most limit production of agronomic and forest crops around the world, as they lead to morphological, physiological, and biochemical changes in plants (Bhanuprakash and Yogeesha, 2016). Salt conditions reduce speed of emergence and seedling development and affect the number of leaves and seeds per plant and seed size and weight (Saberali and Moradi, 2019). In these cases, pre-germination seed treatments was used to increase germination and increase the uniformity of emergence (Cardoso et al., 2015; Pires et al., 2016; Silva et al., 2019). Among these treatments is osmotic priming, a technique that allows control of seed hydration to a level sufficient to allow pre-germination metabolic events, yet insufficient to allow radicle emergence (Bhanuprakash and Yogeesha, 2016; Ramalho et al., 2020).

Favorable seed priming leads to the process of reserve mobilization, activation and de novo synthesis of some enzymes, DNA repair, RNA synthesis, and synthesis of new proteins, making the precursors used in macromolecule synthesis available to the seeds (Hussain et al., 2015).

In determination of plant tolerance to salt stress, one of the most widespread methods is the observation of seed germination capacity, because salinity negatively affects plant growth and development, and its effects depend on the plant species (Larcher, 2000). The excess of soluble salts leads to reduction in soil water potential, reducing water absorption capacity.

Nitric oxide (NO) is an endogenous signaling molecule that plays a fundamental role in the germination of seeds of different species under these conditions. Many studies suggest that application of exogenous NO in the form of sodium nitroprusside (SNP), as NO donor, is involved in an increase in plant tolerance to abiotic stress (Faraji and Sepehri, 2019).

Areas planted to Eucalyptus spp., which includes E. urophylla, in Brazil increased significantly from the end of the first decade of 2000 on, due to a return to exports of cellulose, to the recovery of international prices, and to the initiative of the government in easing the IPI (industrialized products tax) on the industrialized wood panel production chain and on wood furniture (ABRAF, 2019).

In this context, information regarding adaptation of species to salinity are necessary to determine in which locations this species can be planted, as well as to determine required time for germination and seedling stablishment, important factors for ensuring seedling survival (Rosa et al., 2005).

Given the lack of information regarding the effects of salinity on Eucalyptus spp. seeds, it is important to develop studies that evaluate the germination process under this condition alone. Thus, the aim of this study was to evaluate the protective effect of nitric oxide during germination, and seed vigor and seedling development of Eucalyptus urophylla under salt stress conditions.

\section{MATERIAL AND METHODS}

The experiment was conducted in the Central Seed Laboratory of the Department of Agriculture and in the Forest Seed Laboratory of the Department of Forestry Science at the Federal University of Lavras, Minas Gerais. Eucalyptus urophylla seeds provided by the Instituto de Pesquisa e Estudos Florestais - IPEF (Forestry Research and Study Institute) were used that were produced in 2016 and under cold storage at $7{ }^{\circ} \mathrm{C}$ and $50 \% \mathrm{RH}$ in a plastic container up to the time of testing. Seeds were separated with a blower and manually with the assistance of a tweezers until all chaff/hulls were removed.

The $E$. urophylla seeds were placed under physiological conditioning. This was carried out in BOD regulated to $25^{\circ} \mathrm{C}$, without light, for one hour. Priming solutions consisted of distilled water, $0.1 \mathrm{mmol} . \mathrm{L}^{-1}$ potassium nitrate solution (Cardoso et al., 2014), or 0.1 mmol.L-1 sodium nitroprusside solution (Ataíde et al., 2015; Silva et al., 2015; Faraji and Sepehri, 2019). 
Fifty grams of seeds were placed in $200 \mathrm{~mL}$ of solution. The seeds used as control were not primed.

After priming, the seeds were washed in running water, dried in an air circulation laboratory oven for 24 hours at $25{ }^{\circ} \mathrm{C}$, and after that period, once more dried at $35{ }^{\circ} \mathrm{C}$ with air circulation for 24 hours. Moisture content was determined soon after priming (before drying) and after drying of the seeds. For determination of moisture content, four replications of $5 \mathrm{~g}$ of seeds were removed from each treatment, which were placed in a laboratory oven at $105^{\circ} \mathrm{C}$ for 24 hours (Brasil, 2013).

Three different solutions were used on the seeds for the germination test: water and $\mathrm{NaCl}$ salt stress solutions at concentrations that resulted in the potentials of -0.6 and $-1.2 \mathrm{MPa}$.

In the germination test, for all germination conditions, five replications of 20 seeds were sown on two sheets of blotting paper in gerbox boxes (transparent plastic germination boxes), and the blotting paper was moistened with a volume of the various solutions equivalent to 2.5 times the weight of the dry paper. They remained in BOD type chambers with temperature of $25^{\circ} \mathrm{C}$ and $8 / 16$ hour photoperiod. First germination count was made on day 7 and final count on day 14 (Brasil, 2013). In addition, the germination speed index was measured using the germination data according to the proposed by Maguire (1962).

For seedling image analysis, five replications of 20 seeds were sown on two sheets of germitest paper (germination testing paper), and one more sheet was placed over them; they were then moistened with a volume of the various solutions mentioned above, equivalent to 2.5 times the weight of the dry paper. They remained in BOD type chambers with constant temperature of $25^{\circ} \mathrm{C}$ and $8 / 16$ photoperiod. The rolls were placed in plastic bags to prevent loss of moisture. Images of the seedlings were obtained at 14 days after setting up the test, equivalent to the final reading of the germination test (Brasil, 2013).

The GroundEye system, version S200, was used to capture images, which is composed of a image capture module that has an acrylic tray, a high resolution camera, and integrated software for evaluation. The seedlings were removed from the germitest paper and inserted in the tray of the capturing module to obtain images. The analysis configuration step made use of the background color calibration CIELab lightness index from 0 to 100, "a" dimension - 17.5 to 42.5 and " $b$ " dimension from -57.0 to -28.9. After background color calibration, images were analyzed and values of root length and shoot length were determined.

A completely randomized experimental design was used, with five replications, in a $3 \times 3+1$ factorial arrangement, consisting of the three germination solutions and the three priming treatments, plus a control treatment (unprimed seed). The Tukey means test was used on the data at $5 \%$ significance, and the Dunnett test at $5 \%$ probability was performed for comparison of the control with the treatments resulting from the factorial arrangement using the Sisvar 5.6. program (Ferreira, 2014).

\section{RESULTS AND DISCUSSION}

The moisture content of the E. urophylla seeds measured before the beginning of the analyses was $6.5 \%$. The percentage of germination at seven days was higher when the seeds were primed, regardless of the priming solution, and placed to germinate in water, that is, without stress during germination (Table 1). Analysis of interaction with the priming factor shows that sodium nitroprusside (SNP) is effective in protection, regardless of the stress, with a mean of $90 \%$ germination of the seeds; however, for the other priming factors, a reduction in germination is observed as the saline stress concentration increases.

Similar to first germination count, final germination count (Table 1 ) exhibits mean values of $95 \%$ germination when exposed to water, regardless of the priming solution. The SNP led to germination greater than $90 \%$ even when under salt stress, a germination percentage greater than the control treatment at $82 \%$. The other priming solutions responded in a similar manner to first count, with a decline in the number of seeds germinated as salt concentration increased.

Analyzing salt stress individually, the germination speed index (GSI) (Table 1) differed statistically at the greatest 
concentration of sodium chloride ( $\mathrm{NaCl})$, where seeds primed in SNP obtained higher values of GSI, and seeds primed in $\mathrm{KNO}_{3}$ had the lowest value observed.

Salt stress induced by $\mathrm{NaCl}$ led to significant reductions in germination percentage. To germinate, seeds need to reach a level of hydration sufficient to allow reactivation of the metabolism and consequent growth of the embryonic axis; and the greater the amount of water available, associated with greater area of contact, the faster it will be absorbed by seeds (Ramalho et al., 2020).

The movement and availability of water are of considerable importance for germination, initial growth of the root system, and seedling emergence, and these factors are affected by the characteristics of the seed itself and by the characteristics of the colloidal complex of the substrate the seeds are in (Ávila et al., 2007). In addition to these factors, the success of the imbibition phase depends on water potential, that is, the tension that water exerts between the seed and the outside medium.

The reduction in germination percentage of seeds exposed to stress is expected since the presence of solutes and excess of ions reduces water absorption. However, the application of sodium nitroprusside (SNP) at the concentration of $0.1 \mathrm{mmol} . \mathrm{L}^{-1}$ significantly increased the germination percentage of Eucalyptus urophylla seeds. Thus, the SNP may have

Table 1. First germination count (\%), germination (\%), and germination speed index of Eucalyptus urophylla seeds germinated in water and under salt $(\mathrm{NaCl})$ stress at the potentials of -0.6 and $-1.2 \mathrm{MPa}$, without physiological conditioning (control) and under priming in the solutions of water, potassium nitrate $\left(\mathrm{KNO}_{3}\right)$, and sodium nitroprusside (SNP).

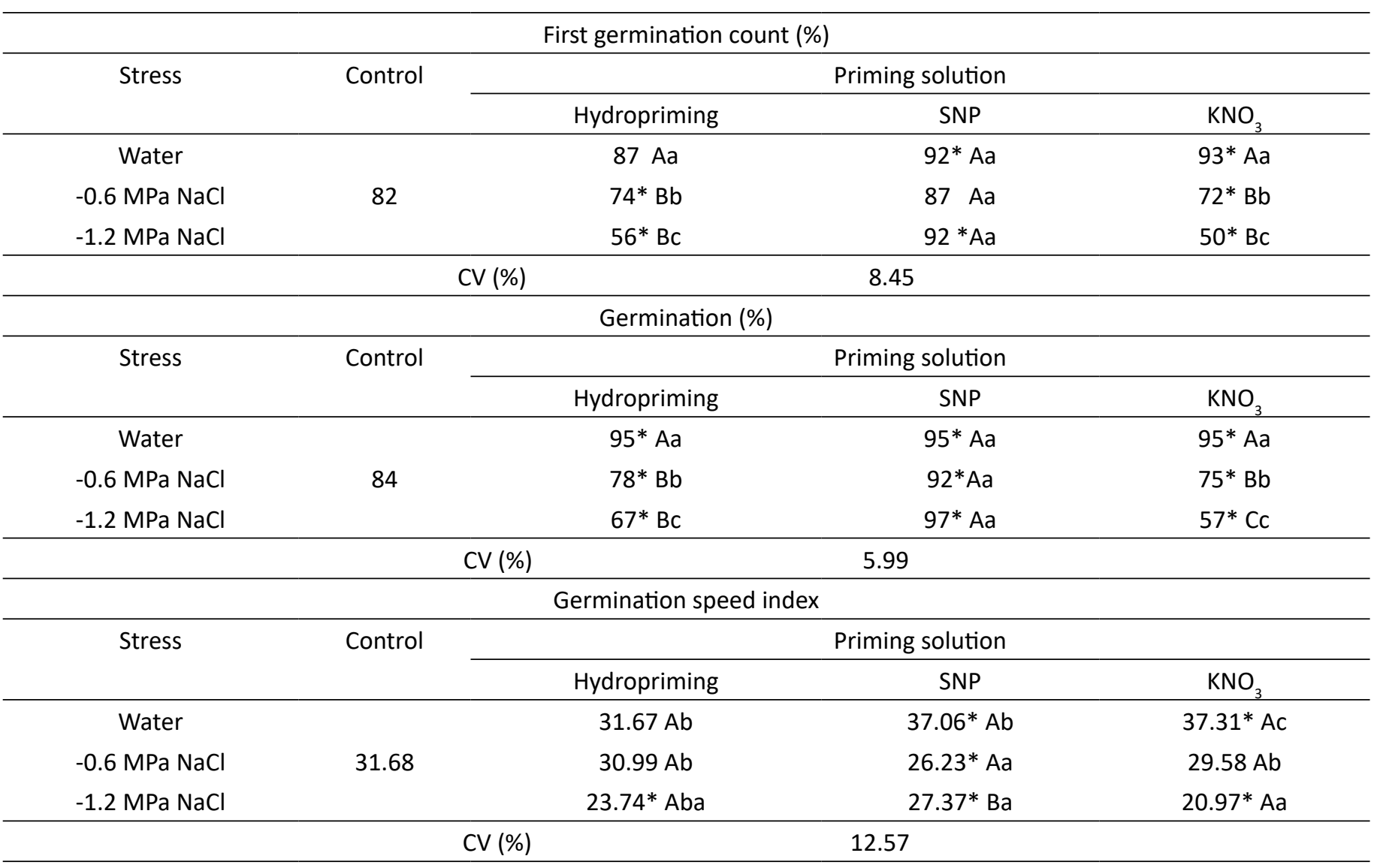

Mean values followed by the same uppercase letter in the row and lowercase letter in the column do not differ from each other by the Tukey test at $5 \%$ probability of error.

*Differ from the control by the Dunnett test at $5 \%$ probability of error.

$\mathrm{CV}=$ coefficient of variation. 
induced breakdown of the superoxide ion, eliminating the reactive oxygen species produced and reducing oxidation. Yet, it is possible that the oxygen produced in this process may also have been consumed in respiration, affecting seed metabolic activity and, consequently, increasing germination percentage (Faraji and Sepehri, 2019).

SNP is a chemical compound with the formula $\mathrm{Na}_{2}\left[\mathrm{Fe}(\mathrm{CN})_{5} \mathrm{NO}\right] \cdot 2 \mathrm{H}_{2} \mathrm{O}$, which serves as a source of nitric oxide (NO). The application of NO donors exercises a protective role in seeds and makes them germinate in greater quantity and at greater speed (Ataíde et al., 2015; Kaiser et al., 2016; Pires et al., 2016). Just as SNP, potassium nitrate ( $\left.\mathrm{KNO}_{3}\right)$ is an NO donor, which for other species, such as Leucaena leucocephala, has a protective effect by counteracting salt stress and priming seeds under low osmotic potential, helping to maintain the physiological quality of that species (Silva et al., 2019). However, for Eucalyptus urophylla seeds, protection was not effective, allowing salt stress to impede the germination, growth, and development of the seedlings.

The mechanisms by which NO stimulates germination have not yet been fully clarified; however, some studies confirm a protective effect that assists in greater germination of seeds due to signaling that acts in interactions with cell targets through redox (Ávila et al., 2007; Silva et al., 2019).

The morphological traits (Table 2) are also sensitive to salt stress and the protective action of SNP. Root length was affected by SNP such that as salt concentration increased, root length increased. However, the other priming solutions acted in a reverse manner on the root, in which the salt solution impeded growth. Thus, in comparison with the control $(1.93 \mathrm{~cm})$, SNP differed statistically in all the treatments, such that the priming solution promoted growth; the other

Table 2. Length $(\mathrm{cm})$ of root, shoot, and total size of seedlings obtained by image analysis of Eucalyptus urophylla seedlings at 14 days of germination in water and salt $(\mathrm{NaCl})$ stress, at the potentials of -0.6 and $-1.2 \mathrm{MPa}$, without physiological conditioning (control) and under priming in the solutions of water, potassium nitrate $\left(\mathrm{KNO}_{3}\right)$, and sodium nitroprusside (SNP).

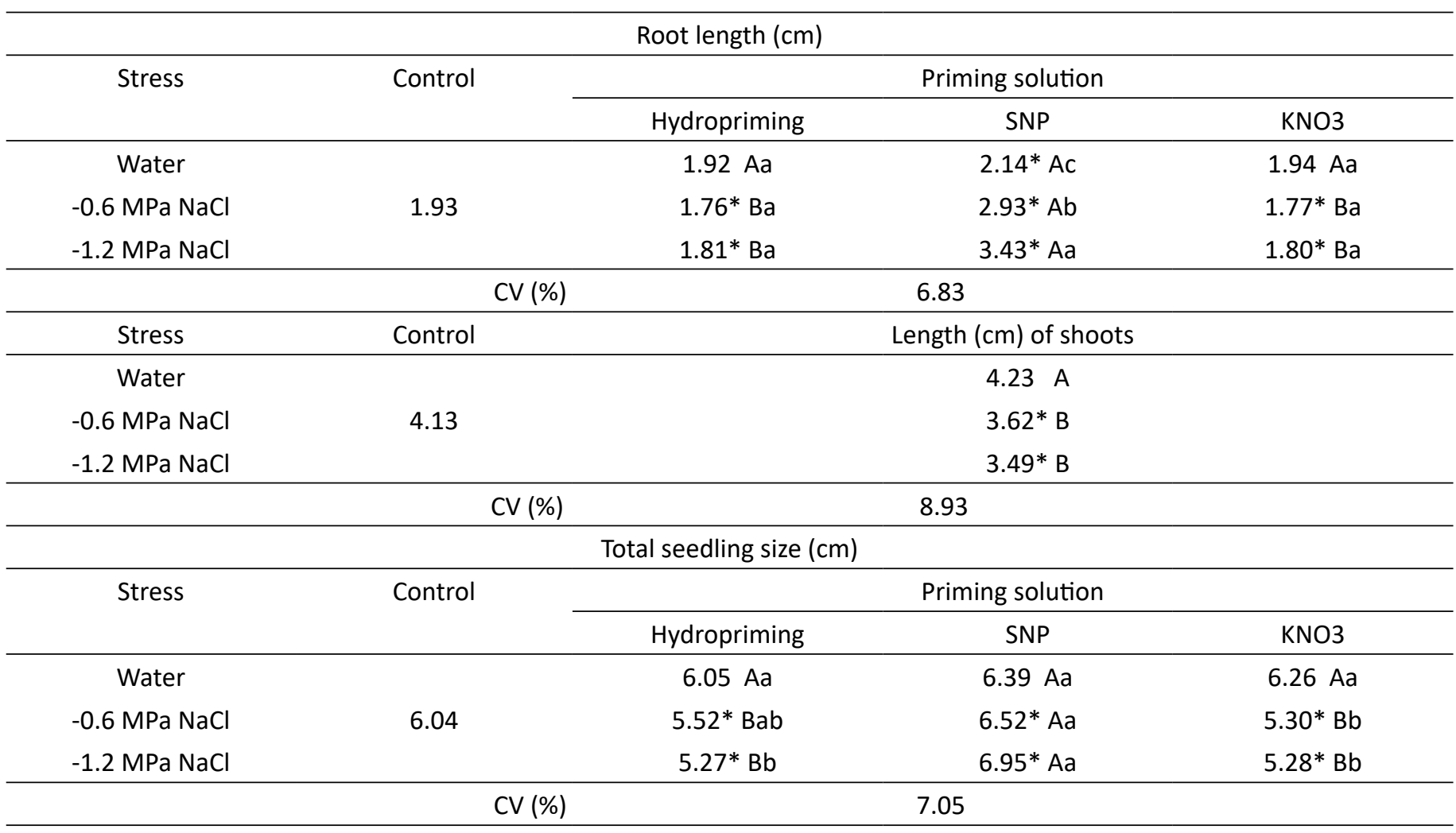

Mean values followed by the same uppercase letter in the. Row and lowercase letter in the column do not differ from each other by the Tukey test at $5 \%$ probability of error.

*Differ from the control by the Dunnett test at $5 \%$ probability of error.

$\mathrm{CV}=$ coefficient of variation. 
solutions differed from the control only in the presence of $\mathrm{NaCl}$, which acted to reduce root growth.

For shoot length of seedlings (Table 2), a statistical interaction between the priming solutions and salt stress was not observed. Thus, regardless of the priming, this stress factor reduced shoot length in the presence of $\mathrm{NaCl}$, statistically differing from the water treatment.

The data in reference to total size of the seedling corroborate with the results of the other morphological parameters. Comparing the saline solution treatments with the control $(6.04 \mathrm{~cm})$, statistical difference is not observed, regardless of the priming solution. Nevertheless, comparison of seedling size among the priming solutions shows that SNP has a protective effect, increasing the size of the seedling in the presence of $\mathrm{NaCl}$. Hydropriming and $\mathrm{KNO}_{3}$ did not differ from each other. Unlike SNP, hydropriming and $\mathrm{KNO}_{3}$ differed upon comparing water with the salt solutions, indicating that the presence of $\mathrm{NaCl}$ reduces seedling size.

It is known that NO releases oxygen molecules and is responsible for extension of the embryo and degradation of reserves under different types of stress conditions. Such information was confirmed by Silva and collaborators (2019), who worked with Leucaena leucocephala seeds also primed in $\mathrm{KNO}_{3}$, and they affirm that this substance, through donating NO, acts in recovery of membrane function, making membranes more stable. It also plays a significant role in mobilization of the main enzymes during seed germination for this species, maintaining homeostasis of iron and promoting its internal transport.

NO is also able to reduce the effects of seed aging (Pereira et al., 2010) and increase tolerance to various abiotic stresses, such as water stress, salt stress, and stress from heavy metals (Silva et al., 2015; Kaiser et al., 2016; Pires et al., 2016). Oxidative stress, brought about by increase in concentration of superoxide, hydrogen peroxide, and alkyl peroxides, can be combatted by NO, since it has antioxidant properties (Silva et al., 2015; Pires et al., 2016).

In addition, NO can react with tyrosines by the nitration process or with thiol residues by oxidation. In the presence of transition metals, such as iron, copper, or zinc, the NO can interact to form metal-nitrosyl complexes. These complexes may be related to the regulatory effects of the transcription factors of NO and certain enzymes (Silva et al., 2015). Tolerance is generated by stimulation of the activity of one or more enzymes of the antioxidant system, such as superoxide dismutase, catalase, peroxidase, and ascorbate peroxidase, reducing the action of reactive oxygen species (ROSs) (Pires et al., 2016).

Silva et al. (2019) indicate that NO stimulates accumulation of ROSs, leading to greater concentration of ethylene that, consequently, can favor the germination process. Thus, SNP would be an antioxidant enzyme-inducing activity, which would reduce the concentration of $\mathrm{H}_{2} \mathrm{O}_{2}$, caused by salt stress modulating the production of ROSs and activity of the antioxidant enzyme, acting as signaling molecules.

The protective role of NO under salt stress is partially connected with its ability to mediate the activity of the antioxidant enzymes already cited and also in direct elimination of the superoxide anion. Nevertheless, it should be emphasized that the ROSs are products of aerobic metabolism and at adequate levels in the cells can perform an essential role in metabolism, such as $\mathrm{H}_{2} \mathrm{O}_{2}$ in cell signaling, in tissue restoration, and in the seed germination process. In this context, $\mathrm{H}_{2} \mathrm{O}_{2}$ is cited as a molecule that, together with $\mathrm{NO}$, can act within a signaling network at cell levels, which will result in oxidative relief caused by abiotic stress in the plants. One of the cell signaling networks through interaction between $\mathrm{H}_{2} \mathrm{O}_{2}$ and $\mathrm{NO}$ is linked to expression of abscisic acid (ABA) (Silva et al., 2019).

NO has the property of mitigating the damage to membranes or even restoring membranes through reduction in the permeability and peroxidation of lipids. Nevertheless, changes in the membrane related to lipid peroxidation involve a complex network with other biochemical mechanisms, controlled by hormones such as ABA (Silva et al., 2019). A hypothesis used by these authors would be the direct effect of NO on the endogenous content of this phytohormone. Sarath et al. (2006) showed that application of SNP partially reverses the inhibitory effects of ABA on germination, on lengthening of the radicle, and on emergence of the coleoptile in Panicum virgatum. This effect was observed for Eucalyptus urophylla upon analyzing the same parameters discussed by Sarath et al. (2006), which showed that priming by SNP promoted tolerance to salt stress. 
For Senna macranthera, SNP favored germination of seeds under salt stress at osmotic potentials of -0.4 and -0.5 $\mathrm{MPa}$ of $\mathrm{NaCl}$ in a $100 \mu \mathrm{M}$ concentration of SNP (Silva et al., 2019). Studies with Leucaena leucocephala showed that salt stress affects seed physiological quality and vigor, but that the application of NO donor substances counteracts the stress from salinity (Silva et al., 2019).

As one of the first organs that emerge from the seed is the radicle, it is the first and main means of contact with the solution, undergoing damage due to stress. Other organs are hurt after transport of the solution, or the harmful effects on the radicle lead to lack of translocation of solutes to the shoots and other structures of the seedling (Hasan et al., 2009). Salt stress reduced root size in Eucalyptus urophylla in hydropriming, whereas priming with SNP led to an increase in root growth.

The increase in root size when the seeds are primed with SNP can be explained through the idea that it performs a role similar to plant hormones, such as cytokinins, gibberellin, and auxin, due to an ability of inducing cell division and proliferation of the plant, as well as tissue differentiation. Salt stress may also have brought about relaxation of the cell wall and induction of cell extension, which consequently has a greater contact surface for absorption of water and greater ability to take up oxygen released by the product during priming (Faraji and Sepehri, 2019).

In seedlings coming from Brassica oleracea L. seeds under salt conditions (-0.6 MPa), Kaiser et al. (2016) found reduction from $4.14 \mathrm{~cm}$ to $1.74 \mathrm{~cm}$ in root growth. These same authors explain that this result, i.e., larger number of abnormal seedlings, is brought about by salinity and is directly associated with the action of the salts through water deficit due to the high osmotic potential of the solution. Furthermore, it exhibits a toxic effect from the ions, which may culminate in metabolic and physiological damage. Du et al. (2015) observed that in Spinacia oleracea plants, salinity (200 $\mathrm{mM} \mathrm{NaCl}$ ) resulted in high levels of toxic substances, such as malondialdehyde (MDA) and hydrogen peroxide $\left(\mathrm{H}_{2} \mathrm{O}_{2}\right)$.

Due to the stress generated by adverse situations, seedlings under salt solution generally tend to invest in greater plant biomass and to develop a greater root system as a survival strategy. Distribution of the root system in depth and also in length because of water insufficiency is considered a tolerance indication parameter and can grant adaptation in some species. It should be noted that such a response is common and is related to the need for greater exploration of the soil in search of water in deeper soil layers (Braga et al., 1999).

The development of total seedling size observed in the treatments in which seeds were previously primed with SNP is due to capture and transport of mineral elements and also to stimulation of molecules that carry water during stress conditions, resulting in greater plant growth (Faraji and Sepehri, 2019).

In response to salt stress, production of ROSs, as singlet oxygen, superoxide, hydroxyl radical, and hydrogen peroxide, is enhanced (Gupta and Huang, 2014; Du et al., 2015; Kaiser et al., 2016; Silva et al., 2019) leading to oxidative damage in various cell components, such as proteins, lipids, and DNA, interrupting vital cell functions of the plants (Liu et al., 2018;). In addition, the high concentration of $\mathrm{Na}^{+}$inhibits capture of $\mathrm{K}^{+}$ions, which is an essential element for growth, and this results in lower yield and may even lead to death (Barbieri et al., 2019).

The increase in salinity results in changes in the ability of the plant in taking up, transporting, and using the ions necessary for its development and reduces the activity of enzymes responsible for respiration and photosynthesis (Gupta and Huang, 2014; Du et al., 2015; Silva et al., 2019). Thus, obtaining energy for development and differentiation of cells in tissues is restricted (Kaiser et al., 2016; Silva et al., 2019). For that reason, knowing the response of the eucalyptus seeds under these conditions is important, especially because of the strong expansion of this crop in various regions of Brazil and the world.

\section{CONCLUSIONS}

Priming promotes increases in germination percentage in Eucalyptus urophylla.

Hydropriming and priming with potassium nitrate are not effective for maintaining seed quality, root protection, and total size of Eucalyptus urophylla seedlings under salt stress conditions. 
Supplying NO through priming with SNP is beneficial, acting as a cell protector, assisting in maintaining germination, vigor, and development of Eucalyptus urophylla seedlings under salt stress conditions.

Physiological priming with SNP promotes an increase in germination percentage, vigor, and development of Eucalyptus urophylla seedlings under salt stress conditions compared to unprimed seeds.

\section{ACKNOWLEDGMENTS}

The authors thank the following funding agencies: the Coordenação de Aperfeiçoamento de Pessoal de Nível Superior (CAPES - Brasil), the Fundação de Amparo à Pesquisa de Minas Gerais (FAPEMIG - Brasil), and the Conselho Nacional de Desenvolvimento Científico e Tecnológico (CNPq).

\section{REFERENCES}

ABRAF. ANUÁRIO ESTATÍSTICO DA ASSOSSIAÇÃO DE PRODUTORES DE FLORESTAS PLANTADAS DO BRASIL. Available on: http:// www.abraflor.org.br/. Accessed on March 20 2019.

ATAÍDE, G.M.; BORGES, E.E.L.; FLORES, A.V.; CASTRO, R. V. Óxido nítrico na germinação de sementes de baixo vigor de Dalbergia nigra. Revista de Ciências Agrárias, v.38, n.3, p.438-444, 2015. http://www.scielo.mec.pt/scielo.php?script=sci_arttext\&pid=S0871$018 \times 2015000300019$

ÁVILA, M.R.; BRACCINI, A.L.; SCAPIM, C.A.; FAGLIARI, J.R; SANTOS, J.L. Influência do estresse hídrico simulado com manitol na germinação de sementes e crescimento de plântulas de canola. Revista Brasileira de Sementes, v.29, n.1, p.98-106, 2007. http:// www.scielo.br/scielo.php?pid=S0101-31222007000100014\&script=sci_arttext\&tlng=pt

BARBIERI, G.F.; STEFANELLO, R.; MENEGAES, J.F.; MUNARETO, J.D.; NUNES, U.R. Seed germination and initial growth of quinoa seedlings under water and salt stress. Journal of Agricultural Science, v.11, n.15, p.153-161, 2019. https://pdfs.semanticscholar. org/e124/388d5913b084935a8a7c0aee932a4254172e.pdf

BHANUPRAKASH, K.; YOGEESHA, H.S. Seed priming for abiotic stress tolerance: an overview. In: Abiotic Stress Physiology of Horticultural Crops, p.103-117, 2016. https://link.springer.com/chapter/10.1007/978-81-322-2725-0_6

BRAGA, L.F.; SOUSA, M.P.; BRAGA, J.F.; SÁ, M.E. Efeito da disponibilidade hídrica do substrato na qualidade fisiológica de sementes de feijão. Revista Brasileira de Sementes, v.21, n.2, p.95-102, 1999. https://www.researchgate.net/profile/Marcilio_Sousa/ publication/287942862_Efeito_da_disponibilidade_hidrica_do_substrato_na_qualidade_fisiologica_de_sementes_de_feijao/ links/56bc95da08ae5e7ba40e71fa.pdf

BRASIL. Ministério da Agricultura, Pecuária e Abastecimento. Instruções para análise de sementes de espécies florestais. Ministério da Agricultura, Pecuária e Abastecimento. Secretaria de Defesa Agropecuária. Brasília: MAPA/ACS, 2013. 98p. https://www.gov. br/agricultura/pt-br/assuntos/insumos-agropecuarios/insumos-agricolas/sementes-e-mudas/publicacoes-sementes-e-mudas/ instrucoes-para-analise-de-sementes-de-especies-florestais/view

CARDOSO, E.D.; SÁ, M.E.; HAGA, K.I.; BINOTTI, F.F.S.; COSTA, E. Qualidade fisiológica e composição química de sementes de Brachiaria brizantha em função do condicionamento osmótico. Journal of Neotropical Agriculture, v.2, n.2, p.42-48, 2015. https:// periodicosonline.uems.br/index.php/agrineo/article/view/264

CARDOSO, E.D.; SÁ, M.E.; HAGA, K.I.; BINOTTI, F.F.S.; NOGUEIRA, D.C.; VALÉRIO-FILHO, W.V. Desempenho fisiológico e superação de dormência em sementes de Brachiaria brizantha submetidas a tratamento químico e envelhecimento artificial. Semina: Ciências Agrárias, v.35, n.1, p.21-37, 2014. https://www.redalyc.org/pdf/4457/445744139002.pdf

DU, S.T.; LIU, Y.; ZHANG, P.; LIU, H.J.; ZHANG, X.Q.; ZHANG, R.R. Atmospheric application of trace amounts of nitric oxide enhances tolerance to salt stress and improves nutritional quality in spinach (Spinacia oleracea L.). Food Chemistry, v.173, n.1, p.905-911, 2015. https://www.sciencedirect.com/science/article/pii/S0308814614016793

FARAJI, J.; SEPEHRI, A. Ameliorative effects of $\mathrm{TiO}_{2}$ nanoparticles and sodium nitroprusside on seed germination and seedling growth of wheat under PEG-stimulated drought stress. Journal of Seed Science, v.41, n.3, p.309-317, 2019. http://www.scielo.br/ scielo.php?pid=S2317-15372019000300309\&script=sci_arttext 
FERREIRA, D. Sisvar: a guide for its bootstrap procedures in multiple comparisons. Ciência e Agrotecnologia, v.32, n.2, p.109-112, 2014. http://www.scielo.br/scielo.php?pid=S1413-70542014000200001\&script=sci_arttext

FIGUEIREDO, F.R.A.; LOPES, M.D.F.Q.; SILVA, R.T.; NÓBREGA, J.S.; SILVA, T.I.; BRUNO, R.D.L.A. Respostas fisiológicas de mulungu submetida a estresse salino e aplicação de ácido salicílico. Irriga, v.24, n.3, p.662-675, 2019. http://revistas.fca.unesp.br/index. php/irriga/article/view/3742

GUPTA, B.; HUANG, B. Mechanism of salinity tolerance in plants: physiological, biochemical, and molecular characterization. International Journal of Genomics, v.2014, p.1-18, 2014. https://www.hindawi.com/journals/ijg/2014/701596/

HASAN, S.A.; FARIDUDDIN, Q.; ALI, B.; HAYAT, S.; AHMAD, A. Cadmium: toxicity and tolerance in plants. Journal of Environmental Biology, v.30, n.2, p.165-174, 2009. http://jeb.co.in/journal_issues/200903_mar09/paper_01.pdf

HUSSAIN, S.; ZHENG, M.; KHAN, F.; KHALIQ, A.; FAHAD, S.; PENG, S.; HUANG, J.; CUI, K.; NIE, L. Benefits of rice seed priming are offset permanently by prolonged storage and the storage conditions. Scientific Reports, v.5, n.1, p.1-12, 2015. https://www.nature. com/articles/srep08101

KAISER, I.S.; MACHADO, L.C.; LOPES, J.C.; MENGARDA, L.H.G. Efeito de liberadores de óxido nítrico na qualidade fisiológica de sementes de repolho sob salinidade. Revista Ceres, v.63, n.1, p.39-45, 2016. https://www.redalyc.org/pdf/3052/305244108006.pdf

LARCHER, W. Ecofisiologia vegetal. Trad. de C.H.B.A. Prado. São Carlos: Rima, 2000. 531p.

LIU, L.; XIA, W.; LI, H.; ZENG, H.; WEI, B.; HAN, S.; YIN, C. Salinity inhibits rice seed germination by reducing $\alpha$-amylase activity via decreased bioactive gibberellin content. Frontiers in Plant Science, v.9, p.275, 2018. https://www.frontiersin.org/articles/10.3389/ fpls.2018.00275/full

MAGUIRE, J.D. Speed of germination - aid in selection and evaluation for seedling emergence and vigor. Crop Science, v.2, n.1, p.176-177, 1962. https://doi.org/10.2135/cropsci1962.0011183X000200020033x

PEREIRA, B.L.C.; BORGES, E.E.L.; OLIVEIRA, A.C.; LEITE, H.G.; GONÇALVES, J.F.C. Influência do óxido nítrico na germinação de sementes de Plathymenia reticulata Benth com baixo vigor. Scientia Forestalis, v.38, n.88, p.629-636, 2010. https://www.ipef.br/ publicacoes/scientia/nr88/cap09.pdf

PIRES, R.M.O.; SOUZA, G.A.; CARDOSO, A.Á.; DIAS, D.C.F.S.; BORGES, E.E.L. Action of nitric oxide in sesame seeds (Sesamum indicum L.) submitted to stress by cadmium. Journal of Seed Science, v.38, n.1, p.22-29, 2016. http://www.scielo.br/scielo.php?pid=S2317$15372016000100022 \&$ script=sci_abstract $\&$ tlng $=$ pt

RAMALHO, L.B.; BENEDITO, C.P.; PEREIRA, K.T.O.; SILVA, K.C.N.; MEDEIROS, H.L.D.S. Hidrocondicionamento de sementes de Piptadenia moniliformis Benth. e seus efeitos sobre a tolerância ao estresse salino. Ciência Florestal, v.30, n.1, p.221-230, 2020. https://www.scielo.br/scielo.php?pid=S1980-50982020000100221\&script=sci_arttext

ROSA, L.S.; FELIPPI, M.; NOGUEIRA, A.C.; GROSSI, F. Avaliação da germinação sob diferentes potenciais osmótico e caracterização morfológica da semente e plântula de Ateleia glazioviana Baill (timbó). Cerne, v.11, n.3, p.306-314, 2005. https://www.redalyc.org/ pdf/744/74411309.pdf

SABERALI, S.F.; MORADI, M. Effect of salinity on germination and seedling growth of Trigonella foenum-graecum, Dracocephalum moldavica, Satureja hortensis and Anethum graveolens. Journal of the Saudi Society of Agricultural Sciences, v.18, n.3, p.316-323, 2019. https://www.sciencedirect.com/science/article/pii/S1658077X17302011

SARATH, G.; BETHKE, P.C.; JONES, R.; BAIRD, L.M.; HOU, G.; MITCHELL, R.B. Nitric oxide accelerates seed germination in warmseason grasses. Planta, v.223, p.1154-1164, 2006. https://link.springer.com/article/10.1007/s00425-005-0162-3

SILVA, A.L.D.; DIAS, D.C.F.S.; RIBEIRO, D.M.; SILVA, L.J.D. Effect of sodium nitroprusside (SNP) on the germination of Senna macranthera seeds (DC. ex Collad.) HS Irwin and Baneby under salt stress. Journal of Seed Science, v.37, n.4, p.236-243, 2015. https://submission3.scielo.br/index.php/jss/article/view/153992

SILVA, A.L.; PINHEIRO, D.T.; BORGES, E.E.L.; SILVA, L.J.; DIAS, D.C.F.S. Effect of cyanide by sodium nitroprusside (SNP) application on germination, antioxidative system and lipid peroxidation of Senna macranthera seeds under saline stress. Journal of Seed Science, v.41, n.1, p.86-96, 2019. http://www.scielo.br/scielo.php?pid=S2317-15372019000100086\&script=sci_arttext 
SILVA, J.A.; SILVA, I.R.F.; DEMARTELAERE, A.C.F.; MEDEIROS, A.D.; PEREIRA, M.D. Physiological quality in Leucaena leucocephala seeds conditioned with potassium nitrate submitted to saline and water stresses. Journal of Experimental Agriculture International, p.1-9, 2019. https://www.researchgate.net/publication/332020958_Physiological_Quality_in_Leucaena_leucocephala_Seeds_ Conditioned_with_Potassium_Nitrate_Submitted_to_Saline_and_Water_Stresses use, distribution, and reproduction in any medium, provided the original work is properly cited. 